\title{
Transgenic expression of phytase and acid phosphatase genes in alfalfa (Medicago sativa) leads to improved phosphate uptake in natural soils
}

\author{
Xue-Feng Ma $\cdot$ Steven Tudor $\cdot$ Twain Butler $\cdot$ \\ Yaxin Ge $\cdot$ Yajun Xi $\cdot$ Joseph Bouton • \\ Maria Harrison $\cdot$ Zeng-Yu Wang
}

Received: 3 May 2011/Accepted: 24 August 2011/Published online: 13 September 2011

(C) The Author(s) 2011. This article is published with open access at Springerlink.com

\begin{abstract}
Alfalfa (Medicago sativa L.) is one of the most widely grown crops in the USA. Phosphate (P) deficiency is common in areas where forage crops are grown. To improve the use of organic phosphate by alfalfa, two Medicago truncatula genes, phytase (MtPHYl) and purple acid phosphatase (MtPAPl), were overexpressed in alfalfa under the control of the constitutive CaMV35S promoter or the root-specific
\end{abstract}

Electronic supplementary material The online version of this article (doi:10.1007/s11032-011-9628-0) contains supplementary material, which is available to authorized users.

X.-F. Ma $\cdot$ S. Tudor $\cdot$ T. Butler $\cdot$ Y. Ge

J. Bouton · Z.-Y. Wang ( $₫)$

Forage Improvement Division, The Samuel Roberts Noble

Foundation, 2510 Sam Noble Parkway, Ardmore,

OK 73401, USA

e-mail: zywang@noble.org

Present Address:

X.-F. Ma

Ceres, Inc., Thousand Oaks, CA 91320, USA

Y. Xi

College of Agriculture, Northwest A and F University,

Yangling 712100, Shaanxi, China

M. Harrison

Boyce Thompson Institute for Plant Research, Ithaca,

NY 14853, USA
MtPT1 promoter. Root enzyme activity analyses revealed that although both genes lead to similar levels of acid phosphatase activities, overexpression of the MtPHYl gene usually results in a higher level of phytase activity than overexpression of the MtPAPl gene. The MtPT1 promoter was more effective than the CaMV35S promoter in regulating gene expression and extracellular secretion under P-deficient conditions. Measurement of growth performance of the transgenic lines further proved that the best promotergene combination is the MtPHYl gene driven by the MtPT1 promoter. Compared to the control, the plants with high levels of transgene expression showed improved growth. The biomass of several transgenic lines was three times that of the control when plants were grown in sand supplied with phytate as the sole $\mathrm{P}$ source. When the plants were grown in natural soils without additional $\mathrm{P}$ supplement, the best performing transgenic lines produced double the amount of biomass after 12 weeks (two cuts) of growth. Transgene effects were more obvious in soil with lower $\mathrm{pH}$ and lower natural $\mathrm{P}$ reserves than in soil with neutral $\mathrm{pH}$ and relatively higher $\mathrm{P}$ storage. The total $\mathrm{P}$ concentration in leaf tissues of the high-expressing transgenic lines was significantly higher than that of the control. The transgenes have great potential for improving plant $\mathrm{P}$ acquisition and biomass yield in P-deficient agricultural soils.

Keywords Alfalfa $\cdot$ Phosphate $\cdot$ Phytase · Purple acid phosphatase $\cdot$ Transgenic plants 


\section{Introduction}

The essential element phosphorus (P) is one of the least available soil nutrients for plant growth (Raghothama and Karthikeyan 2005). For nitrogen-fixing legume species such as alfalfa (Medicago sativa L.), $\mathrm{P}$ is the major limiting nutritional element. Because plants can only absorb inorganic forms of $\mathrm{P}$ from soil, the major portion of soil $\mathrm{P}$ is not available to plants. The concentration gradient of inorganic phosphate (Pi) from soil to plant cells exceeds 2,000-fold, with an average Pi concentration of $1 \mu \mathrm{M}$, which is well below the $K_{\mathrm{m}}$ for plant uptake (Vance et al. 2003). Therefore, $\mathrm{P}$ is frequently the most limiting element for plant growth and development (MacDonald et al. 2011; Vance et al. 2003).

In agriculture, Pi deficiency in soil is countered by the application of $\mathrm{P}$ fertilizer; however, the process is inefficient because up to $80 \%$ of the applied $\mathrm{P}$ fertilizer can be immobilized into forms other than orthophosphate before plant uptake (Holford 1997). Application of phytate-containing manure from non-ruminant animals and the decay of plant seeds and vegetative tissues also contribute significant amounts of organic phosphate (Po) to soil (Turner et al. 2002). As such, soil accumulates a large amount of Po, accounting for $50-80 \%$ of the total $\mathrm{P}$ in soil, of which up to $60-80 \%$ is inositol hexakisphosphates, also known as phytate (Dalal 1977; Turner et al. 2002). Because of their dense negative charges, soil phytates are primarily immobilized as insoluble salts or adsorbed into soil colloids, which prevents them from being biodegraded (Giaveno et al. 2010; Lung et al. 2008) and results in excessive $\mathrm{P}$ loading of prime agricultural land (Vance et al. 2003). Run-off from P-loaded soils to aquatic environments results in eutrophication and damage to ecosystems.

The development of crops with improved $\mathrm{P}$ uptake ability, which can maintain high productivity with reduced inputs of $\mathrm{P}$ fertilizer, will thus provide substantial environmental and economic benefits. One way that plants adapt to $\mathrm{P}$ deficiency is to increase the secretion of acid phosphatases (APases), which catalyze the breakdown of phosphomonoesters with low pH optima (Vincent et al. 1992; Yang and Finnegan 2010). However, in general this adaptive response can secrete only a limited amount of APase to hydrolyze $\mathrm{Po}$ in the rhizosphere and the $\mathrm{Pi}$ released through this mechanism is often not sufficient for plant growth (Hayes et al. 1999; Richardson et al. 2000).

Hydrolytic enzymes that catalyze the stepwise phosphate splitting of phytate or phytic acid are collectively known as phytases (Brinch-Pedersen et al. 2002). Based on amino acid sequence similarities and catalytic mechanisms, at least four phytase families have been classified, including histidine acid phosphatase (HAP), purple acid phosphatase (PAP), $\beta$-propeller phytase (BPP), and cysteine phosphatase (Chan et al. 2006; Lei et al. 2007).

One strategy to increase phytase activities in the rhizosphere, and thus promote $\mathrm{P}$ assimilation from soil, is to overexpress phytase genes in plant roots. To date, several genes have been tested using this strategy, including a HAP phytase gene ( $p h y A)$ from Aspergillus niger, a BPP phytase gene (168phyA) from Bacillus subtilis, a synthetic phytase gene (PHY), a phytase gene (MtPHYl) from M. truncatula and a purple acid phosphatase gene (MtPAPl) from $M$. truncatula. These genes have been introduced into different plant species, including Arabidopsis thaliana, tobacco (Nicotiana tabacum L.), potato (Solanum tuberosum L.), subterranean clover (Trifolium subterraneum L.) and white clover (Trifolium repens L.) (George et al. 2005a, b, 2004; Lung et al. 2005; Ma et al. 2009; Mudge et al. 2003; Richardson et al. 2001; Xiao et al. 2005, 2006a; Yip et al. 2003; Zimmermann et al. 2003). In general, expression of these phytase or acid phosphatase genes led to improved $\mathrm{P}$ nutrition and enhanced growth performance when Po was supplied as the sole $\mathrm{P}$ source.

However, in all the above cases, studies were performed on agar or sand medium, or laboratory amended soil supplemented with Po. When transgenic plants were grown in natural soils without Po supplement, expression of a fungal phytase gene did not improve plant $\mathrm{P}$ nutrition (George et al. 2005b). Encouragingly, a recent study found that constitutive expression of an Arabidopsis APase gene (AtPAP15) increased soybean seed yield under natural soil conditions (Wang et al. 2009). However, since the transgene was constitutively expressed and the APase activity of both old and young leaves was significantly increased under $\mathrm{P}$ stressed conditions, the yield increase of the transgenic plants may be mainly due to enhanced internal $\mathrm{P}$ use efficiency through releasing $\mathrm{Pi}$ from stored phytate/organic $\mathrm{P}$ in the shoots, rather than increased P uptake from the soil (Wang et al. 2009). 
Alfalfa is the fourth most widely grown crop in the USA behind corn, wheat and soybeans (Bouton 2007). A recent study revealed that $\mathrm{P}$ deficits are common in areas growing alfalfa and other forage crops (MacDonald et al. 2011). The yield and persistence of alfalfa is highly affected by P nutrition (Berg et al. 2009). In order to improve $P$ uptake in alfalfa, we produced large numbers of transgenic plants expressing the MtPHYl gene and the MtPAPl gene. Both genes were isolated from the model legume M. truncatula, a close relative of alfalfa. The transgenes were expressed either under control of the constitutive CaMV35S promoter, or under the control of a phosphate transporter (MtPT1) promoter. It has been documented that the MtPT1 promoter leads to rootspecific and low-P inducible expression of transgenes (Xiao et al. 2006b). Plants with high levels of transgene expression were identified by enzyme activity assays and their growth performance in sand culture. Significant improvement in biomass production was achieved when the plants were grown under natural soil conditions without any supplemental $P$. The effects of different genes, promoters and signal sequences were compared to provide information on their utility for potential transgenic strategies to improve plant $\mathrm{P}$ nutrition.

\section{Materials and methods}

Gene constructs and genetic transformation of alfalfa

A phytase gene (MtPHYl) and an acid phosphatase gene (MtPAPl) were isolated from M. truncatula (Xiao et al. 2005, 2006a). The genes were placed under the control of a constitutive CaMV35 promoter or a rootspecific low-P inducible MtPT1 promoter (Xiao et al. 2006b). A patatin signal sequence was used to replace the native signal sequence of the MtPAPl gene. In the present study, six chimeric gene constructs were used, including A: 35S::MtPHY1; B: MtPT1::MtPHY1; C: 35S::MtPAP1; D: MtPT1::MtPAP1; E: 35S::sp':: MtPAP1; and F: MtPT1::sp' $:: M t P A P 1$.

Binary vectors containing the herbicide resistance gene (bar) and the chimeric genes were transferred into the Agrobacterium tumefaciens strain C58 and then transformed into alfalfa (Regen SY-4D) using leaf explants (Austin et al. 1995). All the explants were collected from a single plant line (single genotype). Briefly, leaf tissues were infected with Agrobacterium $\left(\mathrm{OD}_{600}=0.4-0.5\right)$ for $30 \mathrm{~min}$ and then transferred onto a solid co-cultivation medium containing $100 \mu \mathrm{M}$ acetosyringone (ACROS Organics, Morris Plains, NJ, USA) for 3 days. The leaf explants were then transferred to selection medium containing $0.3 \%$ $(\mathrm{w} / \mathrm{v})$ phosphinothricin (PPT) with routine transfers to fresh medium every 2 weeks. Transgenic plants were obtained about 6 months after callus induction. The regenerated plantlets were transferred to the greenhouse once they were well rooted.

Identification of transgenic plants

DNA was isolated from leaf tissue with the DNeasy plant mini kit (Qiagen, Valencia, CA, USA) following the manufacturer's protocol. Transgenic plants were first identified using polymerase chain reaction (PCR) with a pair of primers (forward 5'-CCGTACCGA GCCGCAGGAAC- $3^{\prime}$ and reverse 5'-CAGATCTCG GTGACGGGCAGGAC- $3^{\prime}$ ) amplifying the bar sequence and then confirmed with PCR amplification of the cDNA sequences of MtPHY1 or MtPAP1. The primers used for the amplification of MtPHYl were 5'-CACACTGGATGGACCTT-3' (forward) and 5'-T TACAAGTCACATTATAGAGAAGC- $3^{\prime}$ (reverse). The primers used for the amplification of MtPAPl were 5'-GGCAGAACTAGTACTTTTGT-3' (forward) and $5^{\prime}$-CCACAACTCATGTTTCCCAT-3' (reverse). All PCR reactions were implemented with the GoTaq kit (Promega, Madison, WI, USA) following the manufacturer's instructions.

For Southern hybridization analysis, genomic DNA was isolated from leaf tissues of greenhouse-grown plants following the CTAB procedure (Lichtenstein and Draper 1985). DNA was digested with the restriction enzyme HindIII, which cleaves only once in the binary vector. Twenty micrograms of DNA from each sample were digested overnight and blotted after separation on $1 \%(w / v)$ agarose gel. The hybridization probe was $\left[{ }^{32} \mathrm{P}\right] \mathrm{dCTP}$-labeled using the RadPrime DNA Labeling System (Invitrogen, Carlsbad, CA, USA), and unincorporated nucleotides were removed by passing through ProbeQuant ${ }^{\mathrm{TM}}$ G-50 Micro Columns (Amersham Biosciences, Piscataway, NJ, USA). Gel electrophoresis, DNA blotting and hybridization were carried out following standard protocols (Sambrook et al. 2001). 
Reverse transcription PCR

Root samples were harvested from P-stressed plants 14 days after treatment. Total RNA was isolated from root samples using TRI reagent (Molecular Research Center, Inc., Cincinnati, OH, USA). The RNA samples were treated with DNase I (Invitrogen) to remove any potential genomic DNA contamination. RNA concentrations were estimated by measuring absorbance at $260 \mathrm{~nm}$ followed by visual inspection in agarose gels. Reverse transcription PCR (RT-PCR) was performed using the SuperScript ${ }^{\mathrm{TM}}$ III one-step RT-PCR kit (Invitrogen) with the addition of an internal control, the QuantumRNA ${ }^{\mathrm{TM}}$ universal 18S internal standard (Ambion, Austin, TX, USA). The reaction was prepared following the manufacturer's instructions with minor modifications. Briefly, RT-PCR was performed in a $25-\mu$ l reaction containing $20 \mathrm{ng}$ of total RNA, $0.2 \mu \mathrm{M}$ of each forward and reverse primer, $0.1 \mu \mathrm{M}$ universal $18 \mathrm{~S}$ primer pairs and $0.26 \mu \mathrm{M}$ of $18 \mathrm{~S}$ competimers. The ratio $(1: 2.6)$ of the universal $18 \mathrm{~S}$ primers to the competimers was determined after several tests, allowing comparable amplifications of the 18S rRNA and the target transcripts. The amount of total RNA and the number of PCR cycles were also determined empirically in order to control the amounts of products to be within the linear range of amplification. The reaction was initiated with reverse transcription at $55^{\circ} \mathrm{C}$ for $30 \mathrm{~min}$, followed by $94^{\circ} \mathrm{C}$ for $3 \mathrm{~min}$ and 35 cycles of PCR amplification $\left(94^{\circ} \mathrm{C}\right.$ for $45 \mathrm{~s}, 50^{\circ} \mathrm{C}$ for $45 \mathrm{~s}$ and $72^{\circ} \mathrm{C}$ for $60 \mathrm{~s}$ ) with a final extension at $72^{\circ} \mathrm{C}$ for $5 \mathrm{~min}$. All RT-PCR experiments were repeated twice. The reaction products were resolved by electrophoresis on $1 \%$ $(w / v)$ agarose gels containing ethidium bromide.

\section{Enzyme extraction from P-stressed roots}

Enzyme activities of transgenic alfalfa plants were assayed using whole root extract and root apoplastic sap. All root samples were collected from sand culture after 2 weeks of P stress. The root sample from each plant was collected individually and split into two equal samples, with one for APase extraction and the other for phytase extraction.

The whole root extract was obtained by grinding $\sim 0.5 \mathrm{~g}$ cleaned fresh roots in a mortar and pestle with $5 \mathrm{ml}$ of APase or phytase extraction buffer followed by centrifugation (Eppendorf Refrigerated
Multipurpose $5810 \mathrm{R}$ ) at $2880 \mathrm{~g}$ for $15 \mathrm{~min}$ at $4^{\circ} \mathrm{C}$. The extraction solution used for the phytase assay was the MES/Ca buffer (15 mM MES, $0.5 \mathrm{mM} \mathrm{CaCl}_{2}, \mathrm{pH} 5.5$ ) containing $1 \mathrm{mM}$ EDTA (Richardson et al. 2001). The APase extraction buffer contained $100 \mathrm{mM}$ sodium acetate (pH 5.5), $20 \mathrm{mM} \mathrm{CaCl}_{2}, 1 \mathrm{mM}$ dithiothreitol and $1 \mathrm{mM}$ phenylmethylsulfonyl fluoride (Gilbert et al. 1999).

The root apoplastic sap was expelled from roots using a simplified version of the centrifugation method (Yu et al. 1999). Roots were cleaned with Milli-Q water, blotted dry, cut into $\sim 1-\mathrm{cm}$ segments, and subsequently collected into $0.5-\mathrm{ml}$ Eppendorf tubes with a hole punched (B-D 21G needle) at the bottom of each tube. The root segments were positioned parallel to the tube wall with cut ends pointing to the bottom of the tube. The $0.5-\mathrm{ml}$ tubes were then inserted into 2.0-ml collection tubes and centrifuged at 3,000 $\mathrm{g}$ for $15 \mathrm{~min}$ at $4^{\circ} \mathrm{C}$. To avoid dilution from water residue and contamination from the cytosol of injured cells at the cut ends, the first collection was discarded and new collection tubes were used after a short spin (1 min). The collected root sap samples were used immediately for activity assays.

\section{Enzyme activity assay}

The control and the transgenic plants from all six constructs were analyzed in parallel for both phytase activities and APase activities. The activity of phytase was measured using phytate from rice (Sigma, St. Louis, MO, USA) as the substrate (Richardson et al. 2001). Briefly, $250 \mu \mathrm{l}$ of crude root extract or $10 \mu \mathrm{l}$ of root apoplastic sap was added to a total reaction volume of 500 or $100 \mu \mathrm{l}$, respectively, of the MES/Ca buffer containing $2 \mathrm{mM}$ phytate. The reaction was incubated at $27^{\circ} \mathrm{C}$ for $60 \mathrm{~min}$ and was terminated by the addition of an equal volume of $10 \%$ trichloroacetic acid (TCA). The reaction mixture was then processed for a color reaction, which allows for quantification of the released $\mathrm{Pi}$ compared to standard dilutions of $\mathrm{KH}_{2} \mathrm{PO}_{4}$ (Kim and Lei 2005). The Pi concentration was measured by reading the absorbance at $820 \mathrm{~nm}$ after color development with fresh color reagent at $50^{\circ} \mathrm{C}$ for $15 \mathrm{~min}$ (Kim and Lei 2005). Six replicates were performed for the analysis.

The activity of APase was assayed using $p$-nitrophenyl phosphate ( $p$ NPP, Sigma) as the substrate (Gilbert et al. 1999). The activity was measured with 
an APase assay kit (Sigma) using either $100 \mu \mathrm{l}$ of crude root extract or $10 \mu \mathrm{l}$ of apoplastic sap, following the manufacturer's instructions. A total reaction volume of $1 \mathrm{ml}$ was prepared for each sample and incubated at $37^{\circ} \mathrm{C}$ for $30 \mathrm{~min}$. The reaction was stopped with $2 \mathrm{ml}$ of $0.5 \mathrm{M} \mathrm{NaOH}$, and the released Pi was measured by quantifying the equimolar liberation of $p$-nitrophenol spectrophotometrically at $405 \mathrm{~nm}$ compared to standard $p$-nitrophenol solutions. Data given are the results of six replicates.

Enzyme activity was calculated as pmol per mg protein per min ( $\mathrm{pmol} / \mathrm{mg} / \mathrm{min}$ ) for both APase and phytase activities. The protein concentrations were determined using Bio-Rad DC protein assay reagent with bovine serum albumin as standard (Bio-Rad, Hercules, CA, USA).

\section{Plant propagation}

The transgenic plants as well as the original source plant (Regen SY-4D) were all vegetatively propagated by cuttings in the greenhouse. Thus, all plants are genetically homogeneous across all analyses. After 4 weeks, plantlets with similar sizes were selected and re-potted for different treatments and analyses.

Plant growth for P-stressed root sample collection

For P-stressed root samples for RNA isolation and enzyme activity assays, plantlets propagated from vegetative cuttings were first grown in sand pots. After enough root mass had developed, the plantlets were re-potted with fresh sand and supplied with a nutrient solution that lacked P. Root samples were collected for RNA isolation or enzyme activity assays 2 weeks after $\mathrm{P}$-stressed treatments.

Plant growth in sand supplied with Po

The control and selected lines from each gene construct were planted in $11.5-\mathrm{cm}$ sand pots with one plant in each pot. The plants were supplied with a nutrient solution containing one-third strength MS nutrients (Murashige and Skoog 1962), but using Po instead of Pi. The Po used was phytate isolated from rice as myo-inositol hexaphosphoric acid dodecasodium salt (Sigma). Each pot was fertilized weekly with $10 \mathrm{ml}$ nutrient solution for the first 3 weeks and with $15 \mathrm{ml}$ per week afterwards. The plants were grown in growth chambers under a day/night regime of $25 / 20^{\circ} \mathrm{C}$ and $14 / 10 \mathrm{~h}$ in fluorescent light $\left(240 \mu \mathrm{E} \mathrm{m}^{-2} \mathrm{~s}^{-1}\right)$. Total dry weight (DW) of the above-sand tissues was measured 6 weeks after cultivation. The DW was obtained after oven-drying for a week at $65^{\circ} \mathrm{C}$. Four replicates were done for all selected transgenic individuals as well as the control.

Plant growth in soils without any P supplement

Plants were grown in $20-\mathrm{cm}$ pots filled with natural soil in growth chambers. Two soil types were collected: soil 1 is acidic ( $\mathrm{pH}$ 5.0) with a sandy loam texture and relatively low $\mathrm{Pi}$ and total $\mathrm{P}$ storage; soil 2 is close to neutral ( $\mathrm{pH}$ 6.7) with a loam texture and moderate $\mathrm{P}$ reserve. The details of the two soil types, as analyzed by a private analytical lab (Ward Laboratory, Kearney, NE, USA) are provided in Table 1. Plantlets with similar leaf and root mass were planted in the soils with one in each pot. For the first 3 weeks after planting, the plants were watered only with distilled water without any nutritional supplement. In the following weeks, plants were provided each week with $15 \mathrm{ml}$ of one-third-strength MS nutrients, but without any forms of $\mathrm{P}$. Thus, at later stages of growth, the only nutrient deficiency that plants could encounter would be $P$ stress if the original soil did not have adequate $P$ reserves. The components of the non-P-containing nutrient solution applied to the

Table 1 Characterization of the two soils used in the present study

\begin{tabular}{lll}
\hline & Soil 1 & Soil 2 \\
\hline Location & Vashti, TX & Ardmore, OK \\
Soil series & Bonti & Durant \\
Soil texture & Sandy loam & Loam \\
Total P (mg P kg-1) & 159.5 & 299.0 \\
Extractable P $\left(\mathrm{mg} \mathrm{P} \mathrm{kg}^{-1}\right)$ & 2.6 & 10.9 \\
Organic matter $(\%)$ & 1.0 & 3.7 \\
Soil pH & 5.0 & 6.7 \\
Nitrate-N $\left(\mathrm{mg} \mathrm{N} \mathrm{kg}^{-1}\right)$ & 1.4 & 10.2 \\
Potassium $\left(\mathrm{mg} \mathrm{K} \mathrm{kg}^{-1}\right)$ & 51.5 & 166.0 \\
Calcium $\left(\mathrm{mg} \mathrm{Ca} \mathrm{kg}^{-1}\right)$ & 356.0 & $1,704.0$ \\
Magnesium $\left(\mathrm{mg} \mathrm{Mg} \mathrm{kg}^{-1}\right)$ & 99.0 & 332.0 \\
Sodium $\left(\mathrm{mg} \mathrm{Na} \mathrm{kg}^{-1}\right)$ & 12.0 & 15.0 \\
Aluminum $\left(\mathrm{mg} \mathrm{Al} \mathrm{kg}^{-1}\right)$ & 53.6 & 0.5 \\
Sum of cations $\left(\mathrm{mEq}^{-1} 100 \mathrm{~g}\right)$ & 8.4 & 11.9 \\
\hline
\end{tabular}


two soils are the same, but with different $\mathrm{pH}$. In order to maintain the original soil $\mathrm{pH}$ levels throughout the growth period, the $\mathrm{pH}$ values of the non-P-containing nutrients were adjusted to their original soil $\mathrm{pH}$ levels, i.e. 5.0 and 6.7 for soil 1 and soil 2, respectively. For biomass evaluation, two cuts were performed. The first cut was done 8 weeks after planting, and the second cut was taken 4 weeks after the first cut. Dry weights of the two cuts for each plant were recorded separately. The experiment had six replications.

\section{Measurement of total $\mathrm{P}$}

The second cut tissues from plants grown in the soil were used for total $\mathrm{P}$ measurement. Leaves $(100 \mathrm{mg}$ ) were collected in $13 \times 100 \mathrm{~mm}$ glass tubes and $50 \mu \mathrm{l}$ of $10 \% \mathrm{Mg}\left(\mathrm{NO}_{3}\right)_{2}$ solution was added to each tube. The samples were dried and ashed by shaking over strong flames until the brown fumes disappeared. The ash samples were dissolved in $1.5 \mathrm{ml}$ of $0.5 \mathrm{M} \mathrm{HCl}$ and used for Pi determination by colorimetric assay at OD820 (Ames 1966). Data given are the result of four replicates.

\section{Data analysis}

Data are presented as mean \pm standard error (SE), except where noted. Regression lines are given where correlation analyses are presented. Details of additional significance tests are provided in the Electronic Supplementary Material Tables for plant screening studies, such as enzyme activity assays and sand growth tests. Least significant difference (LSD) tests were performed for comparisons between transgenic individual plants and the control. Group mean tests were used to compare different constructs that involve various genes, promoters or signal peptides. Differences in slope were used to compare two regression lines. All of the above statistical analyses used Student's $t$ test for significance.

\section{Results}

Transgenic expression of MtPHYl and MtPAPI genes in alfalfa

Two MtPHY1 gene constructs [35S::MtPHY1 (A) and MtPT1::MtPHY1 (B)] and four MtPAP1 constructs [35S::MtPAP1 (C), MtPT1::MtPAP1 (D),

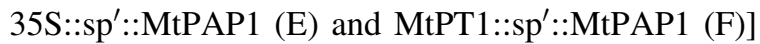
were introduced into alfalfa by Agrobacterium-mediated transformation. The chimeric genes were expressed under control of the constitutive CaMV35S promoter or the root-specific MtPT1 promoter (Xiao et al. 2006b). In addition, the patatin signal sequence $\left(\mathrm{sp}^{\prime}\right)$ was introduced to replace the native signal peptides of the MtPAPl gene. Forty to sixty alfalfa plants were regenerated for each gene construct.

The regenerated plants were screened by PCR amplification of the bar gene and the MtPHYl or $M t P A P 1$ sequence. The transgenic nature of the plants was confirmed by Southern hybridization analysis using genomic DNA digested with HindIII, an enzyme that has only one cleavage site in the T-DNA region. To avoid cross-hybridization, a bar gene fragment was labeled as the probe. Hybridization bands were observed in all transgenic plants analyzed, and most plants contained a single band (Suppl. Fig. 1a). The presence of hybridization bands of different sizes revealed that the plants were independent transformants and that the transgenes were stably integrated into the plant genome. Since all explants used for transformation were from a single genotype which has been maintained through vegetative propagation, all transgenic plants and the control should have an isogenic background.

To test the expression levels of the MtPHY1 or $M t P A P 1$ genes in transgenic alfalfa, the transgenic and control plants were grown in sand pots under P-stressed conditions. Root tissues were collected for RNA isolation 14 days after P-deficient treatment. RT-PCR analysis revealed various levels of expression among different individuals (Suppl. Fig. 1b). No obvious difference was observed between different gene constructs, since each construct has individuals covering a broad range of gene expression levels from low to high. Representative transgenic lines were selected for enzyme activity assays of root APase and phytase.

Based on RT-PCR analysis, a total of 60 transgenic plants from the six gene constructs were chosen for enzyme activity assays. In order to better understand the substrate preference of the released enzymes, both phytase and APase activities were measured for each plant, regardless of the chimeric gene (MtPHYl or $M t P A P 1)$ used. The assays were carried out using phytase and APase extracts from the root tissues after 
2 weeks of growth under P-deficient conditions. In addition, all analyses were done in parallel using both whole root extract and root apoplastic sap of each plant, in order to check extracellular secretion of the enzymes.

Root APase activities of the transgenic MtPHYl and MtPAPl plants

APase catalyzes the breakdown of phosphomonoesters, and thus the APase activity of the extracted enzyme should represent its general ability to degrade most forms of organic phosphate. In the present study, the APase activities were measured using $p$ NPP and the results are plotted in Fig. 1 (for statistical details see Suppl. Table 1). For whole root extract, it is evident that APase activities of almost all transgenic plants (except for B4, C3, C7 and E7) were higher than that of the control, though large variations exist among different transgenic lines (Fig. 1a, b, Suppl. Table 1a). The average transgenic enzyme activity showed an approximately threefold increase and the highest (plant B5 of Fig. 1a) activity was 4.4-fold that of the control. Out of the 60 transgenic plants, 11 (A4, B5, B6, B9, B11, D2, D8, E5, E8, F4 and F8) showed an activity
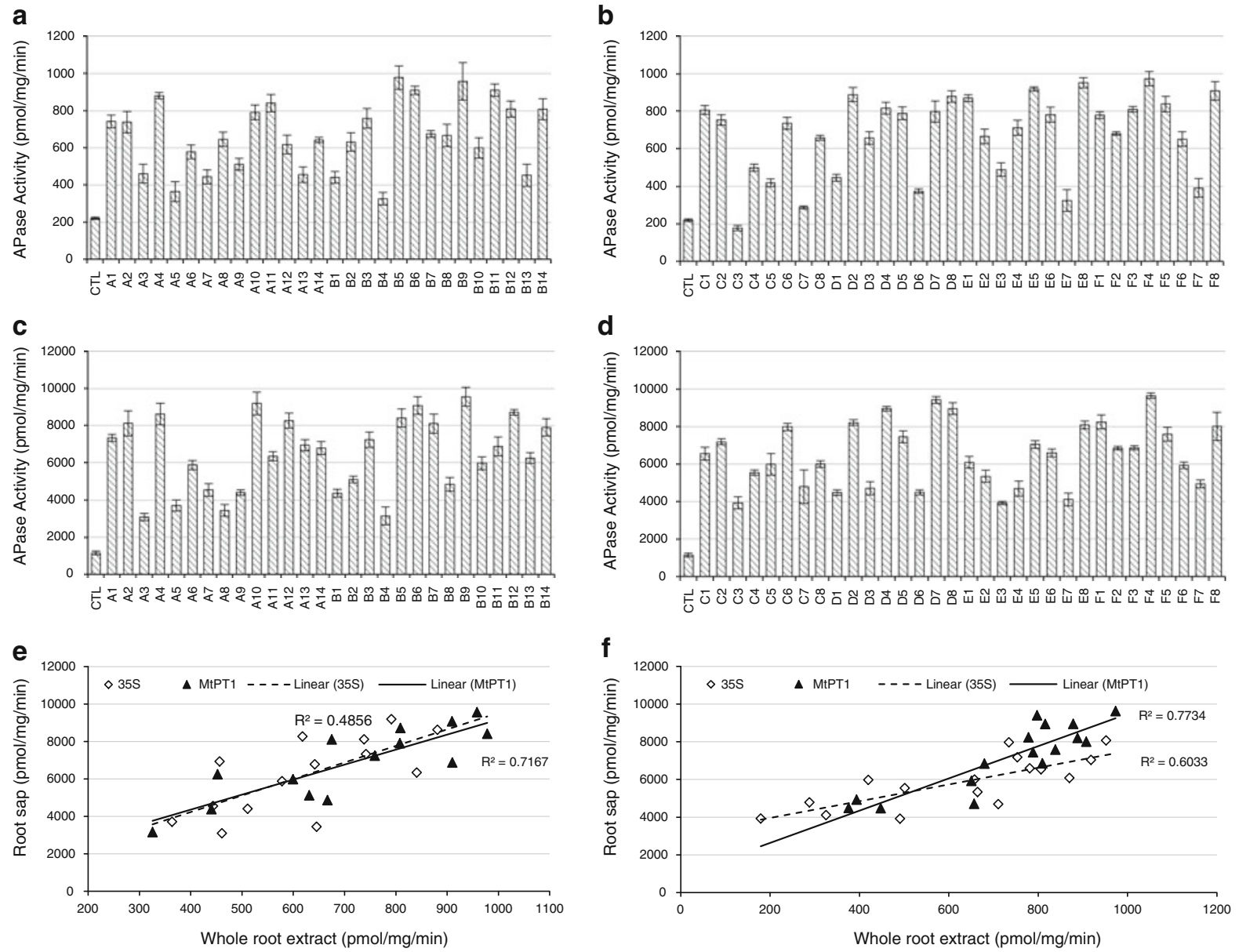

Fig. 1 APase activity of transgenic and control $(C T L)$ alfalfa plants. The first letter of each plant name represents the gene construct used for producing the transgenic line. a Activities of whole root extracts of the MtPHY1 plants. b Activities of whole root extracts of the MtPAP1 plants. c Activities of root saps of

the MtPHY1 plants. d Activities of root saps of the MtPAP1 plants. e Activity correlation between whole root extracts and root saps of the MtPHY1 plants. f Activity correlation between whole root extracts and root saps of the MtPAP1 plants. Data are presented as means $\pm \operatorname{SE}(n=6)$ 
increase of greater than fourfold compared to the control (Fig. 1a, b).

When root sap was used for enzyme assays, the difference in APase activity between the transgenic lines and the control was more evident (Fig. 1c, d, Suppl. Table 1c). All the transgenic lines showed much higher APase activities than the control with an average 5.7-fold increase in activity in the root sap. The highest lines (A10, B9, D7 and F4) had a more than 8.0-fold increase in APase activity compared to the control. No significant difference in secretion efficiencies was found between the native and the patatin signal peptide $\left(\mathrm{sp}^{\prime}\right)$ sequences $(P=0.1494$ and 0.9438, group mean tests of CD vs. EF in Suppl. Tables $1 \mathrm{~b}$ and $1 \mathrm{~d})$.

The two promoters also showed different effects for both MtPHY1 and MtPAPl constructs. The starting transgenic population size was very similar between different constructs, and the plants carrying transgenes driven by the MtPT1 promoter showed higher enzyme activities than the plants carrying 35S-promoterdriven transgenes $(P=0.0660$ and 0.0328 , group mean tests of ACE vs. BDF in Suppl. Tables $1 \mathrm{~b}$ and 1d). For example, the average APase activity in root extracts of the $14 \mathrm{MtPT} 1$-promoter-driven MtPHY1 plants was $708 \mathrm{pmol} / \mathrm{mg} / \mathrm{min}$, and the corresponding value of the $1435 \mathrm{~S}$-promoter-driven MtPHYI lines was $622 \mathrm{pmol} / \mathrm{mg} / \mathrm{min}$ (Fig. 1a).

To examine the extracellular secretion of the expressed enzymes, the correlation between APase activities in whole root extracts and the activities in root sap was analyzed (Fig. 1e, f). Statistical tests indicated that APase activities of whole root extracts are significantly related to the activities in root sap $(P=0.0056$ or smaller) for all gene constructs (Fig. 1e, f, Suppl. Tables 1e and 1f). However, a stronger and more significant correlation was observed between root extracts and root saps for the MtPT1 promoter plants $\left(r^{2}=0.7167\right.$ or $\left.0.7734, P<0.0001\right)$ compared to the $35 \mathrm{~S}$ promoter plants $\left(r^{2}=0.4857\right.$ or $0.6033, P=0.0056$ or 0.0004$)$ for both MtPHY1 and MtPAPl constructs (Fig. 1e, f, Suppl. Tables 1e and 1f). Noticeably, while the slope is similar $(P=$ 0.7833 ) between $35 \mathrm{~S}$ and MtPT1 of MtPHY1 plants (Fig. 1e), the slope is significantly different $(P=0.0141)$ between the $35 \mathrm{~S}$ and the MtPT1 promoters of MtPAPl plants (Fig. 1f). This implies a much more efficient APase translocation to the apoplastic space when the MtPAPl gene was controlled by the MtPT1 rather than the $35 \mathrm{~S}$ promoter (Suppl. Tables 1e and 1f).

Both transgenic MtPHYl and MtPAPl plants were able to produce APase effectively under low $\mathrm{P}$ conditions and there was no significant difference in overall APase activities between the MtPHYl and the MtPAPl plants $(P=0.7940$ and 0.9969 , group mean tests of AB vs. CDEF in Suppl. Tables $1 b$ and 1d).

Root phytase activities of transgenic MtPHYl and $M t P A P 1$ plants

Since phytate is the most abundant $\mathrm{P}$ species in soil, it is essential to know how effectively phytate can be degraded by the enzymes expressed by the two transgenes, MtPHYl and MtPAP1. Phytase activities were measured using the substrate phytate for both genes (Fig. 2, Suppl. Table 2).

All the transgenic plants showed higher phytase activities than the control, in both whole root extracts and root apoplastic saps, although activities in some whole root extracts were not significantly different from that of the control (Fig. 2a-d, Suppl. Tables 2a and 2d). However, an obvious difference in phytase activity was observed between the two genes although this difference was not seen in the APase activity assay. The transgenic MtPHYl plants generally showed higher phytase activities than the MtPAPl plants for both whole root extracts and root apoplastic saps (Fig. 2a-d), suggesting that phytate can be more easily degraded by MtPHY1 than by MtPAP1, even though they have similar levels of APase activities. For example, in whole root extracts, the average phytase activity of MtPHY1 plants was 2.8 times that of the control and the highest phytase activity (line B5) was 4.8 times that of the control, while average phytase activity of the MtPAP1 plants was 2.1 times that of the control, and the highest phytase activity (line F4) was 3.7 times that of the control (Fig. 2a, b).

Similar to APase activities, phytase activities in root apoplastic saps were much higher than in whole root extracts. The average phytase activities showed 5.9- and 5.2-fold increases compared to the control for MtPHY1 and MtPAP1 plants, respectively. The highest phytase activities in root apoplastic saps were 9.1 (line B5) and 7.7 times (line F4) that of the control for the MtPHYl and MtPAPl genes, respectively (Fig. 2c, d). This increased phytase activity in root sap 

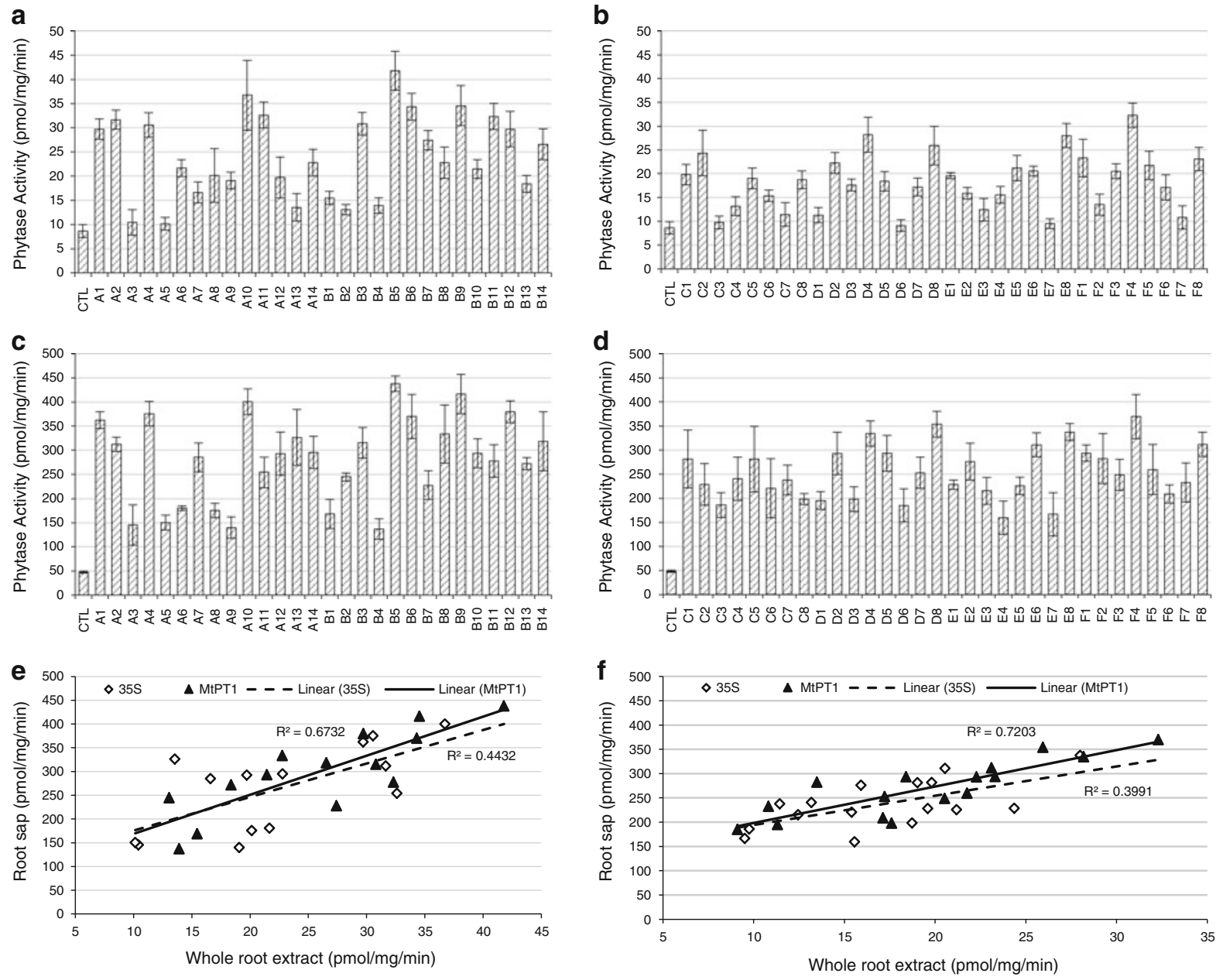

Fig. 2 Phytase activity of transgenic and control (CTL) alfalfa plants. The first letter of each plant name represents the gene construct used for producing the transgenic line. a Activities of whole root extracts of the $M t P H Y 1$ plants. b Activities of whole root extracts of the MtPAP1 plants. c Activities of root saps of

collections compared to whole root tissue extracts again suggested that the expressed enzymes were extracellularly secreted to the rhizosphere. A strong correlation was also seen between phytase activities of root extracts and sap collections (Figs. 2e, f, Suppl. Tables 2e and 2f).

Correlation between APase and phytase activities in MtPHYl and MtPAPl plants

The above analyses showed that the transgenic plants expressing MtPHYl or MtPAPl all have both APase and phytase activities. It is interesting to know the

the MtPHY1 plants. d Activities of root saps of the MtPAP1 plants. e Activity correlation between whole root extracts and root saps of the MtPHY1 plants. f Activity correlation between whole root extracts and root saps of the MtPAP1 plants. Data are presented as means $\pm \operatorname{SE}(n=6)$

relationship between APase and phytase activities (between Figs. 1, 2) for each gene because the substrate preferences of the two expressed enzymes are different.

The correlations between APase and phytase activities of the two genes are plotted in Suppl. Figure 2 (detailed in Suppl. Table 3). APase activity is highly correlated with phytase activity for both MtPHY1 and MtPAP1 (Suppl. Tables 3a and 3b). The $R^{2}$ values of the APase and phytase activities are 0.84 and 0.71 in the whole root extracts, and 0.71 and 0.60 in the root saps for MtPHYl and MtPAPl genes, respectively. Therefore, a good estimation of phytase 
activity can be obtained by measuring APase activity in a transgenic plant.

The difference in data distribution for the two genes is evident in Suppl. Fig. 2, especially in Suppl. Fig. 2a. The slope of the correlation line for the two enzyme activities for $M t P H Y 1$ is significantly steeper than that of MtPAP1 $(P<0.0001$ for whole root extracts and $P=0.0446$ for root apoplastic saps; Suppl. Tables 3a and $3 \mathrm{~b}$ ); the MtPHYl gene also has many more data points distributed in the upper space than the MtPAPl when enzyme activities were measured with both root extracts and sap (Suppl. Fig. 2). The results again clearly showed that phytase activities are usually higher in MtPHYl plants than in MtPAPl plants when they have similar levels of APase activities (Suppl. Fig. 2). For example, the APase activities in root extracts of lines B5 and F4 were very close, at 978 and $973 \mathrm{pmol} / \mathrm{mg} / \mathrm{min}$ (Fig. 1a, b), respectively, but their phytase activities were significantly different, at 42 and $32 \mathrm{pmol} / \mathrm{mg} / \mathrm{min}$ (Fig. 2a, b), respectively. On average, when the APase activity levels were close between $M t P H Y 1$ and MtPAPl transgenic lines, phytase activities of MtPAP1 plants were about $25 \%$ lower in root extracts and $10 \%$ lower in root saps when compared to those of MtPHY1 plants (Suppl. Tables 3).

Growth performance of transgenic alfalfa in sand supplied with phytate

Transgenic alfalfa plants with relatively high enzyme activity were selected for a growth test in sand under controlled nutrient conditions. Four or five plants were selected from each of the MtPHYI and MtPAPI constructs. Throughout the growth period, the plants were supplied with modified MS nutrients (Murashige and Skoog 1962) using Po (phytate) instead of Pi; thus the growth performance of a plant in a sand pot should be highly correlated with its ability to use phytate as its source of $\mathrm{P}$. The above-sand tissues were collected for dry weight evaluation 6 weeks after planting (Fig. 3, Suppl. Table 4). Although large biomass variations were observed between different transgenic plants, the total dry weight for most of the transgenic lines was higher than that of the control. Plants carrying the MtPT1-MtPHY1 gene construct generally grew better than the other constructs because of the combination of the MtPT1 promoter and the MtPHYl gene (as illustrated in Suppl. Tables 1 and 2). While many transgenic plants showed an approximately twofold increase in dry weight compared to the control, the dry weights of several transgenic plants, including A10, B5, B6, B9, B11, D4 and F4, were about three times that of the control (Fig. 3). All the lines that showed high biomass in sand had high levels of enzyme activities, indicating a direct relationship between transgene expression, enzyme activity and biomass accumulation.

Growth performance of transgenic alfalfa in natural soils

Selected transgenic plants were grown in natural soils collected from two different field locations. The soils represent two soil textures (sandy loam and loam),

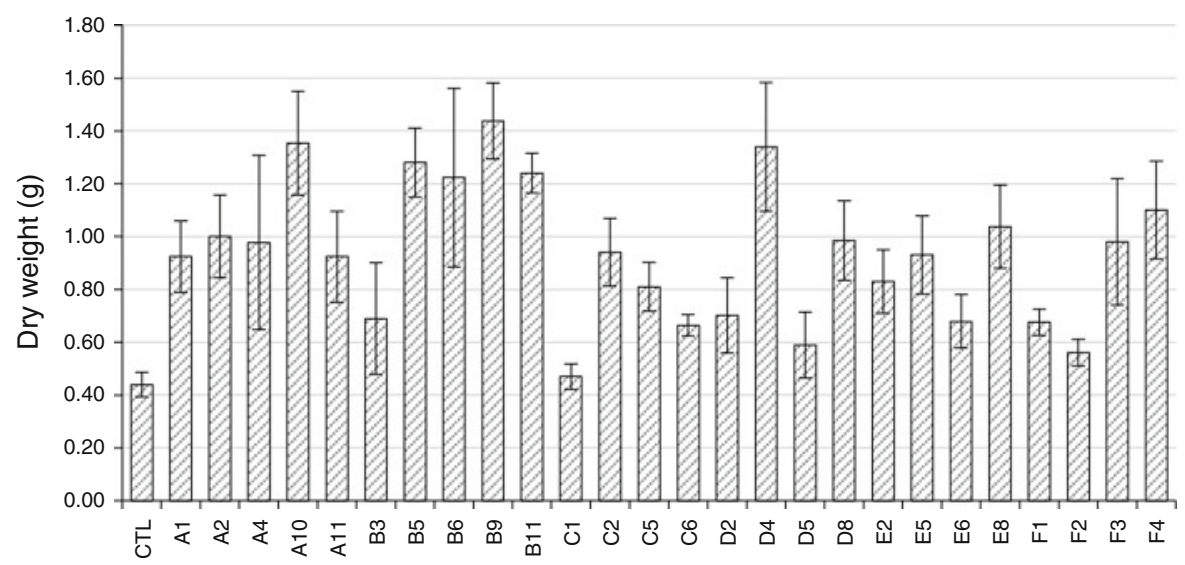

Fig. 3 Biomass of transgenic alfalfa and control plants in sand supplied with phytate as the only $\mathrm{P}$ source. Data are presented as the means $\pm \operatorname{SE}(n=4)$ of the dry weights 
different soil $\mathrm{pH}$ (5.0 and 6.7), different extractable (Mehlich III) or plant-available P (2.6 and $10.9 \mathrm{mg} \mathrm{P}$ $\mathrm{kg}^{-1}$ ), and total $\mathrm{P}$ levels (160 and $299 \mathrm{mg} \mathrm{P} \mathrm{kg}^{-1}$ ), as detailed in Table 1. These differences between soils are common in the southern Great Plains. For example, sandy soils typically have lower soil $\mathrm{pH}$ and less available nutrients compared to loam soils. The available $\mathrm{P}$ in soil 1 is very low for adequate plant growth, and soil 2 is moderately low in $\mathrm{P}$ for optimal alfalfa production.

Plantlets of the selected lines were grown in the two soils without any supplemental $\mathrm{P}$ throughout the growth period. Since the starting plantlets were very small, it was assumed that nutrients in the soil should be sufficient for the initial growth and establishment, and thus no nutrients were applied during the first 3 weeks of growth, allowing consumption of the reserved nutrients in the soils. A non-P-containing nutrient solution was applied to each soil starting in the fourth week after planting to ensure that the plants were not stressed by lack of any other nutrient components. Thus, the only nutrient deficit that could limit plant growth is $\mathrm{P}$ deficiency.

The biomass of each plant was calculated by combining dry weights of two cuts during the test period (Fig. 4). The first cut was done 8 weeks after planting, and the second cut was taken after another 4 weeks of regrowth after the first cut.

The overall results showed a difference in growth performance between the two soil types (Fig. 4). However, a good correlation was observed between growth in soil 1 and other analyses such as root enzyme activities and growth performance in sand (Fig. 4a). For example, the best-performing five plants (A10, B9, D8, E8 and F4) in soil 1 all demonstrated high root enzyme activities and generally showed better growth in sand pots. This consistent performance from enzyme activities, growth in sand and growth in soil 1 indicated that the transgenes played their expected roles in soil 1 . The dry weight of the most improved line (B9) doubled that of the control. In soil 2, the transgene effect was less obvious, even though several transgenic lines showed higher total biomass than the control. Compared to the control, the best performer in soil 1 (B9) showed a $31 \%$ increase in biomass production when it grew in soil 2 (Fig. 4b).

Comparison of the two soil conditions (Table 1) revealed that at least two factors, $\mathrm{pH}$ and the amount of $\mathrm{P}$ reserve, could affect the effectiveness of the transgenes. The $\mathrm{pH}$ of soil 1 is 5.0 , within the optimal $\mathrm{pH}$ range for APase or phytase enzyme functionality in general; however, the $\mathrm{pH}$ of soil 2 is close to neutral $(\mathrm{pH}$ 6.7), which is not an ideal working $\mathrm{pH}$ for the enzymes. It is important to note that soil pH 6.7 (soil 2) is optimal for alfalfa production, while the low soil $\mathrm{pH} 5.0$ (soil 1) will limit alfalfa production because nutrients, especially $\mathrm{P}$, become limiting at extreme soil $\mathrm{pH}$ levels. The $\mathrm{pH}$ of each soil was maintained throughout the growth period because the non-P-containing nutrient solution applied to each soil was $\mathrm{pH}$-adjusted to the same level as the original $\mathrm{pH}$ of the soil. As a result, the enzymes released from the root in soil 1 consistently had a better working $\mathrm{pH}$ condition than in soil 2 . In addition, the total $\mathrm{P}$ reserve in soil 1 is about half that of soil 2 ; in particular, the free $\mathrm{P}(\mathrm{Pi})$ concentration of soil 1 is only about a quarter that of soil 2 (Table 1). Consequently, the plants grown in soil 1 showed better transgene effects when compared to the control because they encountered more severe $\mathrm{P}$ stress; this stress may induce earlier and/or higher transgene expression than in the plants grown in soil 2, especially for the low-P inducible promoter MtPT1. In other words, the transgenic effects in soil 2 were less apparent due to greater $\mathrm{P}$ reserves in the soil, though many other factors could also affect growth of the plants.

Total P concentrations of the plants grown in natural soils

Total $\mathrm{P}$ concentrations were measured using the second-cut leaf tissues harvested from the soil-grown plants. The $\mathrm{P}$ concentrations of five transgenic lines and the control were measured and are shown in Fig. 4c. While several transgenic plants showed a significant increase in total $\mathrm{P}$ concentration in both soils, the transgene effect in soil 1 was again more pronounced than in soil 2. Compared to the control $\mathrm{P}$ concentration, the two plants with highest $\mathrm{P}$ concentrations (B5 and B9) in soil 1 increased 51 and 56\%. In soil 2, the increases in $\mathrm{P}$ concentration of the two bestperforming plants (A4 and B9) were 13 and 22\%, respectively.

\section{Discussion}

It has been shown that expression of MtPHYl and MtPAPl in Arabidopsis led to improved utilization 

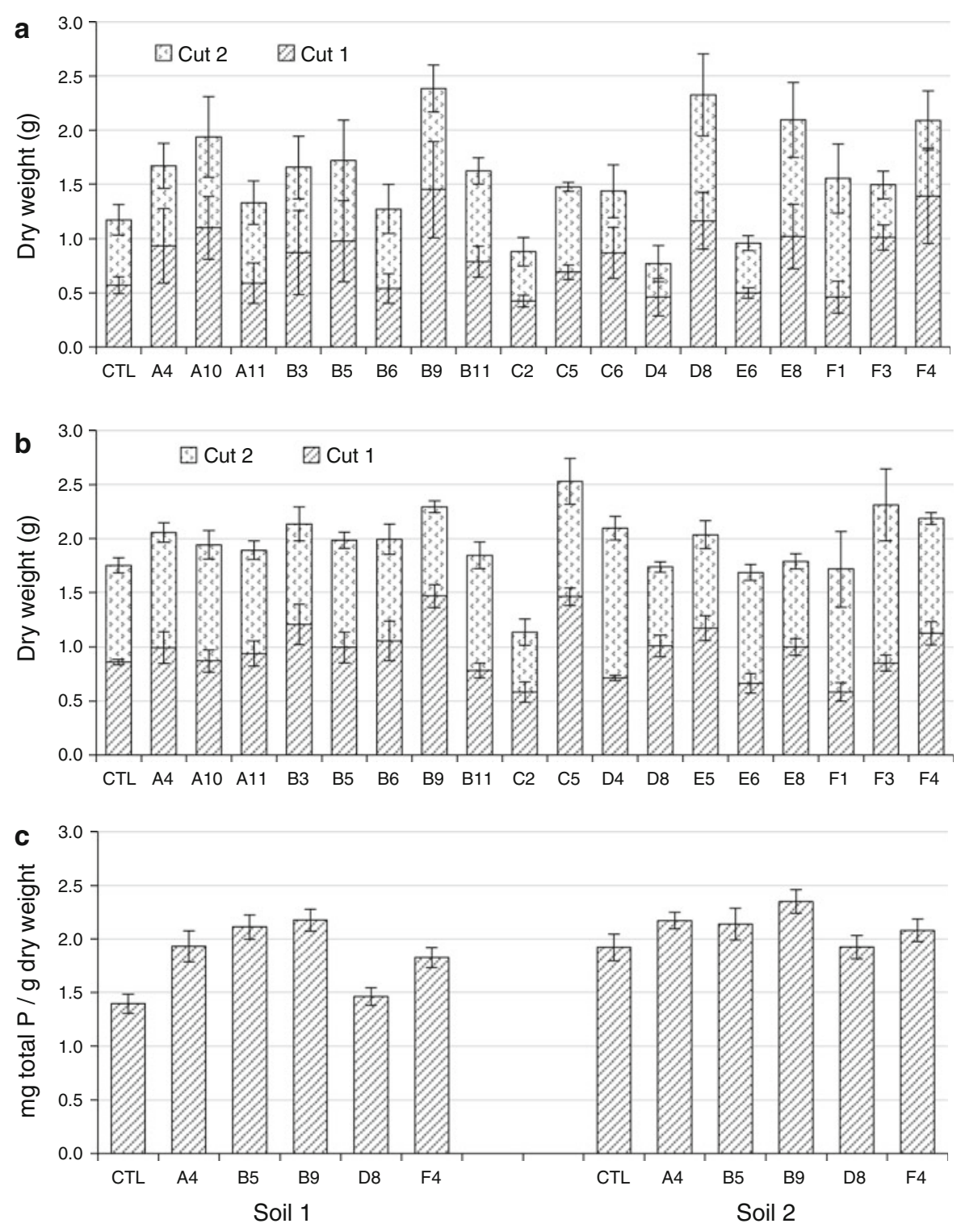

Fig. 4 Biomass and total $\mathrm{P}$ concentration in leaf tissues of transgenic alfalfa and control plants in two types of soils without any P supply. a Soil 1 has a low $\mathrm{pH}$ and low P reserves. b Soil 2 has a neutral $\mathrm{pH}$ with higher $\mathrm{P}$ reserves than soil 1 . For both soils, the first cut was done 8 weeks after planting and the

of Po in MS medium (Xiao et al. 2005, 2006a). However, the effectiveness of these two genes could not be compared because they were analyzed in two different studies. In addition, substrate preferences of the genes were not documented, as only one substrate was used in each study. Though the predicted amino acid sequence of MtPHY1 is distant from that of $M t P A P 1$, with only $34 \%$ shared identity (Xiao et al. second cut was done 4 weeks after the first cut. Data are presented as means $\pm \operatorname{SE}(n=6)$ of the dry weight. $\mathbf{c}$ Total $\mathrm{P}$ concentration in leaf tissues obtained from second cut of transgenic alfalfa and control plants grown in soil 1 and soil 2 . Data are presented as means $\pm \operatorname{SE}(n=4)$

2006a), a recent study suggested that both $M t P H Y 1$ and MtPAP1 belong to the purple acid phosphatase (PAP) family (Lung et al. 2008). Therefore, it is interesting to further characterize the two genes and compare their effectiveness in $\mathrm{P}$ acquisition. In the present study, the two genes were transformed into alfalfa, one of the most valuable crops in the USA. Although alfalfa is an outcrossing species, the explant we used for 
transformation was vegetatively propagated from a single genotype, and thus all transgenic plants have an isogenic background.

The results clearly demonstrate that while transgenic MtPHY1 and MtPAPl plants have similar abilities to cleave $p$ NPP, the MtPHYl plants degrade phytate more effectively than the MtPAPl lines. Therefore, MtPHY1 has enhanced phytate preference and will be more useful in agriculture than MtPAP1. These results were further supported by the growth performance in sand and soils, especially in soil 1 , where MtPHY1 plants generally grew better than MtPAP1 plants when the transgenes were expressed under the control of the same promoter. Since phytate was the only substrate in sand and the major substrate in soils, the difference in substrate preference between the two enzymes may also explain why there was a better correlation in plant growth between sand and soils for MtPHYl lines than for MtPAPI lines.

Two promoters, a root-specific low-P inducible MtPT1 promoter and a constitutive $35 \mathrm{~S}$ promoter, were compared in this study. Although both promoters successfully directed over-expression of MtPHYl or MtPAPl in alfalfa, the MtPT1 promoter was found to be more effective in regulating gene expression and extracellular secretion under P-deficient conditions. When enzyme activities were at similar levels in the whole root extracts, their activities in root saps were generally higher if the transgenes were controlled by the MtPT1 promoter. This consistent tendency of the two genes suggests a more effective enzyme translocation from intracellular to extracellular space if the transgenes were driven by the MtPT1 promoter rather than the $35 \mathrm{~S}$ promoter. Considering the results of the promoter comparisons, it is evident that the best transgene combination should be the MtPHYl gene driven by the MtPT1 promoter. Indeed, transgenic lines bearing the MtPT1-MtPHY1 construct generally grew better than plants carrying the other gene constructs.

The presence of a signal peptide has been shown to play an important role in directing secreted enzymes to the apoplast ( $\mathrm{Li}$ et al. 1997; Richardson et al. 2001). The MtPHYl and MtPAPl genes contain native signal sequences. A patatin signal sequence was used in the $M t P A P 1$ constructs to compare its effectiveness with the native signal sequence. Significant increases of enzyme activities in root apoplasts compared to whole root extracts indicated that the enzymes accumulated mainly in the extracellular space due to the presence of the signal peptides. The patatin signal and the native signal sequences showed similar efficiency in directing extracellular secretion of the enzymes to the rhizosphere.

Most previous work on expressing phytase or APase genes used model plant species (George et al. 2005a, b, 2004; Lung et al. 2005; Mudge et al. 2003; Richardson et al. 2001; Xiao et al. 2005, 2006a; Yip et al. 2003), and most growth data were obtained by growing transgenic plants on laboratory agar medium, hydroponics and sand cultures with supplemented Po (George et al. 2005a, b, 2004; Lung et al. 2005; Ma et al. 2009; Mudge et al. 2003; Richardson et al. 2001; Xiao et al. 2005, 2006a; Yip et al. 2003; Zimmermann et al. 2003). However, despite the ability to accumulate more $\mathrm{P}$ in agar medium or phytate-amended soils, transgenic plants expressing a fungal phytase gene did not show improved $\mathrm{P}$ acquisition when grown in unamended P-deficient soils (George et al. 2005b). Therefore, it is imperative to test transgene effects in real agricultural soil. The only report on soil testing of transgenic plants showed that constitutively overexpressing an APase gene improved soybean yield, but the yield increase was mainly due to increased internal $\mathrm{P}$ use efficiency rather than enhanced $\mathrm{P}$ acquisition from the soil (Wang et al. 2009). In the present study, the use of a root-specific promoter, MtPT1, excluded the possibility of affecting internal translocation of $\mathrm{P}$ from shoots. In fact, the rootspecific promoter was more effective in improving $\mathrm{P}$ uptake compared to the constitutive promoter. This study thus clearly demonstrated, for the first time, that transgenic expression of phytase and APase genes leads to improved $\mathrm{P}$ acquisition from natural agricultural soils.

The effects of transgenes varied with the type of soils tested. The $\mathrm{pH}$ level, the amount and form of $\mathrm{P}$ storage and the soil texture affected the $\mathrm{P}$ utilization of the transgenic plants. Since optimal $\mathrm{pH}$ for the enzymes is below neutral, the effects of the two genes should be higher in acidic soils, as exemplified in soil 1. P deficiency often occurs in acidic soils, which are prevalent in many areas of the world. The transgenes, particularly the MtPT1-MtPHY1 combination, should prove useful for improving $\mathrm{P}$ uptake in acidic soils, allowing farmers to reduce $\mathrm{P}$ inputs while retaining high yields, and reducing $\mathrm{P}$ runoff from agricultural soils. 
Acknowledgments The work was supported by the Samuel Roberts Noble Foundation.

Open Access This article is distributed under the terms of the Creative Commons Attribution Noncommercial License which permits any noncommercial use, distribution, and reproduction in any medium, provided the original author(s) and source are credited.

\section{References}

Ames BN (1966) Assay of inorganic phosphate, total phosphate and phosphatases. In: Neufeld E, Ginsburg V (eds) Methods in enzymology. Academic Press, New York, pp 115-118

Austin S, Bingham ET, Mathews DE, Shahan MN, Will J, Burgess RR, Cassells AC, Jones PW (1995) Production and field performance of transgenic alfalfa (Medicago sativa L.) expressing alpha-amylase and manganese-dependent lignin peroxidase. Euphytica 85:381-393

Berg WK, Cunningham SM, Brouder SM, Joern BC, Johnson $\mathrm{KD}$, Volenec JJ (2009) Influence of phosphorus and potassium on alfalfa yield, taproot $\mathrm{C}$ and $\mathrm{N}$ pools, and transcript levels of key genes after defoliation. Crop Sci 49:974-982

Bouton J (2007) The economic benefits of forage improvement in the United States. Euphytica 154:263-270

Brinch-Pedersen H, Sorensen LD, Holm PB (2002) Engineering crop plants: getting a handle on phosphate. Trends Plant Sci 7:118-125

Chan W-L, Lung S-C, Lim BL (2006) Properties of betapropeller phytase expressed in transgenic tobacco. Protein Expr Purif 46:100-106

Dalal RC (1977) Soil organic phosphorus. Adv Agron 29:83-117

George TS, Richardson AE, Hadobas PA, Simpson RJ (2004) Characterization of transgenic Trifolium subterraneum $\mathrm{L}$. which expresses phyA and releases extracellular phytase: growth and $\mathrm{P}$ nutrition in laboratory media and soil. Plant Cell Environ 27:1351-1361

George T, Richardson A, Smith J, Hadobas P, Simpson R (2005a) Limitations to the potential of transgenic Trifolium subterraneum L. plants that exude phytase when grown in soils with a range of organic P content. Plant Soil 258: 263-274

George TS, Simpson RJ, Hadobas PA, Richardson AE (2005b) Expression of a fungal phytase gene in Nicotiana tabacum improves phosphorus nutrition of plants grown in amended soils. Plant Biotechnol J 3:129-140

Giaveno C, Celi L, Richardson AE, Simpson RJ, Barberis E (2010) Interaction of phytases with minerals and availability of substrate affect the hydrolysis of inositol phosphates. Soil Biol Biochem 42:491-498

Gilbert GA, Knight JD, Vance CP, Allan DL (1999) Acid phosphatase activity in phosphorus-deficient white lupin roots. Plant Cell Environ 22:801-810

Hayes JE, Richardson AE, Simpson RJ (1999) Phytase and acid phosphatase activities in extracts from roots of temperate pasture grass and legume seedlings. Aust J Plant Physiol 26:801-809
Holford ICR (1997) Soil phosphorus: its measurement, and its uptake by plants. Aust J Soil Res 35:227-239

Kim TW, Lei XG (2005) An improved method for a rapid determination of phytase activity in animal feed. J Anim Sci 83:1062-1067

Lei X, Porres J, Mullaney E, Brinch-Pedersen H (2007) Phytase: source, structure and application. In: Polaina J, MacCabe AP (eds) Industrial enzymes. Springer, Dordrecht, The Netherlands, pp 505-529

Li J, Hegeman CE, Hanlon RW, Lacy GH, Denbow DM, Grabau EA (1997) Secretion of active recombinant phytase from soybean cell-suspension cultures. Plant Physiol 114:1103-1111

Lichtenstein C, Draper J (1985) Genetic engineering of plants. In: Glover DM (ed) DNA cloning. IRL Press, Oxford, pp 67-119

Lung S-C, Chan W-L, Yip W, Wang L, Yeung EC, Lim BL (2005) Secretion of beta-propeller phytase from tobacco and Arabidopsis roots enhances phosphorus utilization. Plant Sci 169:341-349

Lung S-C, Leung A, Kuang R, Wang Y, Leung P, Lim B-L (2008) Phytase activity in tobacco (Nicotiana tabacum) root exudates is exhibited by a purple acid phosphatase. Phytochemistry 69:365-373

Ma X-F, Wright E, Ge Y, Bell J, Xi Y, Bouton JH, Wang Z-Y (2009) Improving phosphorus acquisition of white clover (Trifolium repens L.) by transgenic expression of plantderived phytase and acid phosphatase genes. Plant Sci 176:479-488

MacDonald GK, Bennett EM, Potter PA, Ramankutty N (2011) Agronomic phosphorus imbalances across the world's croplands. Proc Natl Acad Sci USA 108: 3086-3091

Mudge SR, Smith FW, Richardson AE (2003) Root-specific and phosphate-regulated expression of phytase under the control of a phosphate transporter promoter enables Arabidopsis to grow on phytate as a sole P source. Plant Sci $165: 871-878$

Murashige T, Skoog F (1962) A revised medium for rapid growth and bioassays with tobacco tissue culture. Physiol Plant 15:473-497

Raghothama K, Karthikeyan A (2005) Phosphate acquisition. Plant Soil 274:37-49

Richardson AE, Hadobas PA, Hayes JE (2000) Acid phosphomonoesterase and phytase activities of wheat (Triticum aestivum L.) roots and utilization of organic phosphorus substrates by seedlings grown in sterile culture. Plant Cell Environ 23:397-405

Richardson AE, Hadobas PA, Hayes JE (2001) Extracellular secretion of Aspergillus phytase from Arabidopsis roots enables plants to obtain phosphorus from phytate. Plant $\mathbf{J}$ 25:641-649

Sambrook J, Russell DW, Maniatis T (2001) Molecular cloning: a laboratory manual. Cold Spring Harbor Laboratory Press, New York

Turner BL, Papházy MJ, Haygarth PM, McKelvie ID (2002) Inositol phosphates in the environment. Phil Trans R Soc Lond B Biol Sci 357:449-469

Vance CP, Uhde SC, Allan DL (2003) Phosphorus acquisition and use: critical adaptations by plants for securing a nonrenewable resource. New Phytol 157:423-447 
Vincent JB, Crowder MW, Averill BA (1992) Hydrolysis of phosphate monoesters: a biological problem with multiple chemical solutions. Trends Biochem Sci 17:105-110

Wang X, Wang Y, Tian J, Lim BL, Yan X, Liao H (2009) Overexpressing AtPAP15 enhances phosphorus efficiency in soybean. Plant Physiol 151:233-240

Xiao K, Harrison M, Wang Z-Y (2005) Transgenic expression of a novel $M$. truncatula phytase gene results in improved acquisition of organic phosphorus by Arabidopsis. Planta 222:27-36

Xiao K, Katagi H, Harrison M, Wang Z-Y (2006a) Improved phosphorus acquisition and biomass production in Arabidopsis by transgenic expression of a purple acid phosphatase gene from M. truncatula. Plant Sci 170:191-202

Xiao K, Liu J, Dewbre G, Harrison M, Wang Z-Y (2006b) Isolation and characterization of root-specific phosphate transporter promoters from Medicago truncatula. Plant Biol 8:439-449

Yang XJ, Finnegan PM (2010) Regulation of phosphate starvation responses in higher plants. Ann Bot 105:513-526

Yip W, Wang L, Cheng C, Wu W, Lung S, Lim B-L (2003) The introduction of a phytase gene from Bacillus subtilis improved the growth performance of transgenic tobacco. Biochem Biophys Res Commun 310:1148-1154

Yu Q, Tang C, Chen Z, Kuo J (1999) Extraction of apoplastic sap from plant roots by centrifugation. New Phytol 143: 299-304

Zimmermann P, Zardi G, Lehmann M, Zeder C, Amrhein N, Frossard E, Bucher M (2003) Engineering the root-soil interface via targeted expression of a synthetic phytase gene in trichoblasts. Plant Biotechnol J 1:353-360 